Памяти одного из пионеров изучения подводных вулканов Курильской островной дуги Г.Б. Удинцева посвящается

\title{
ПОДВОДНЫЙ ВУЛКАНИЧЕСКИЙ МАССИВ РИКОРДА (КУРИЛЬСКАЯ ОСТРОВНАЯ ДУГА)
}

(С 2018 г. Ю. И. Блох ${ }^{1,}$ *, В. И. Бондаренко ${ }^{2}$ А. С. Долгаль ${ }^{3}$, П. Н. Новикова ${ }^{3}$ В. В. Петрова О. В. Пилипенко ${ }^{5}$ В. А. Рашидов ${ }^{1, * *}$, А. А. Трусов ${ }^{6}$

${ }^{1}$ Институт вулканологии и сейсмологии ДВО РАН 683006 Петропавловск-Камчатский, бульвар Пийпа, 9, Россия

${ }^{2}$ Костромской ГУ им. Н.А. Некрасова

156961 Костоома, ул. 1 Мая, 16, Россия

${ }^{3}$ Горный институт УрО РАН

614007 Пермь, ул. Сибирская, 78а, Россия

${ }^{4}$ Геологический институт РАН

109017 Москва, Пыжкевский пер., 7, Россия

${ }^{5}$ Институт физики Земли им. О.Ю. Шмидта РАН

123995 Москва, ул. Б. Грузинская, 10, стр. 1, Россия

${ }^{6}$ АО “ГНПП Аэрогеофизика"

125373 Москва, Походный проезд, 19, Россия

*e-mail:yuri_blokh@mail.ru

**e-mail: rashidva@kscnet.ru

Поступила в редакцию 15.05.2017 г.

\begin{abstract}
Изучено строение подводного вулканического массива Рикорда, состоящего из четырех сливающихся по основанию вулканических построек, и имеющего, скорее всего, четвертичный возраст. На начальных этапах жизни вулканического массива изливались базальтовые и андезибазальтовые лавы. Высокие значения естественной остаточной намагниченности драгированных пород обусловлены большим содержанием однодоменных и псевдооднодоменных зерен титаномагнетита и магнетита. Установлены направления подводящих каналов и наличие периферических магматических очагов. Построена объемная модель центральной части вулканического массива Рикорда, в которой выделено десять крупных магнитовозмущающих блоков, которые, вероятнее всего, являются застывшими субвертикальными подводящими каналами.
\end{abstract}

DOI: $10.1134 / \mathrm{S} 0203030618040028$

\section{ВВЕДЕНИЕ}

Вытянутый в субмеридиональном направлении подводный плосковершинный вулканический массив Рикорда, названный в честь известного отечественного мореплавателя, исследователя дальневосточных морей адмирала Петра Ивановича Рикорда [Безруков и др., 1958], располагается в Центральных Курилах в центральной части одноименного пролива между островами Кетой и Ушишир (рис. 1).

Массив Рикорда исследован в рейсах Института океанологии АН СССР в 1949-1955 гг. и в 5-ти рейсах Института вулканологии ДВО АН СССР на научно-исследовательском судне
(НИС) “Вулканолог” в 1982-1991 гг. [Безруков и др., 1958; Подводный вулканизм ..., 1992]. В рейсах на НИС “Вулканолог” были выполнены эхолотный промер, непрерывное сейсмоакустическое профилирование (НСП), модульная гидромагнитная съемка (ГМС) и драгирование привершинной части подводного вулканического массива [Аникин и др., 2017; Блох и др., 2013, 2014, 2015, 2017; Бондаренко, Рашидов, 2007, 2011a, 2011б; Подводный вулканизм ..., 1992].

Описание результатов исследований, выполненных в рейсах НИС “Вулканолог” и в современных геофизических лабораториях на драгированном каменном материале, представлено в настоящей работе. 
(a)

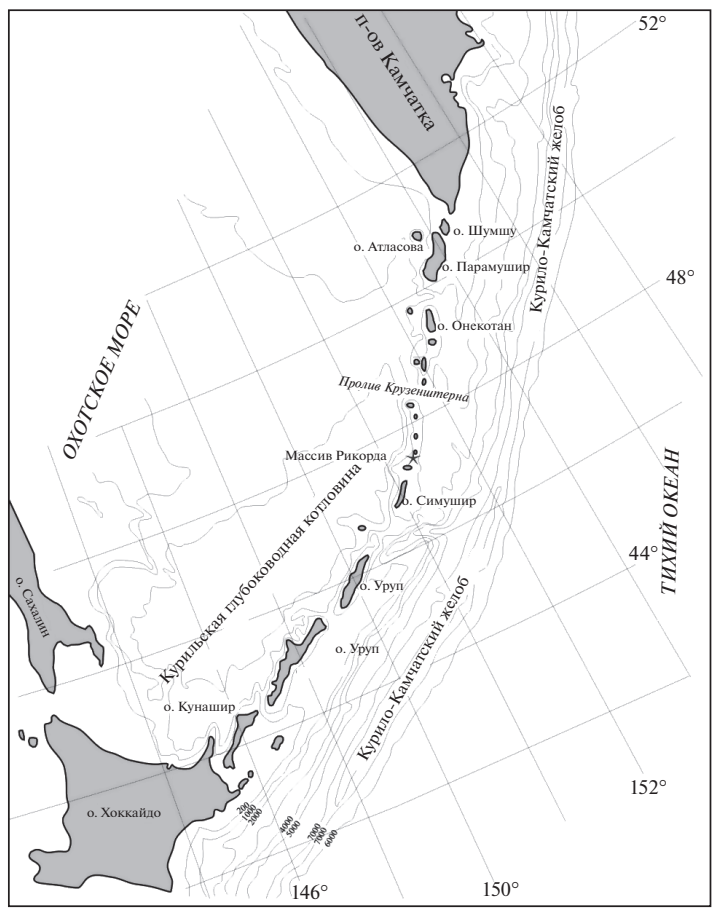

(б)

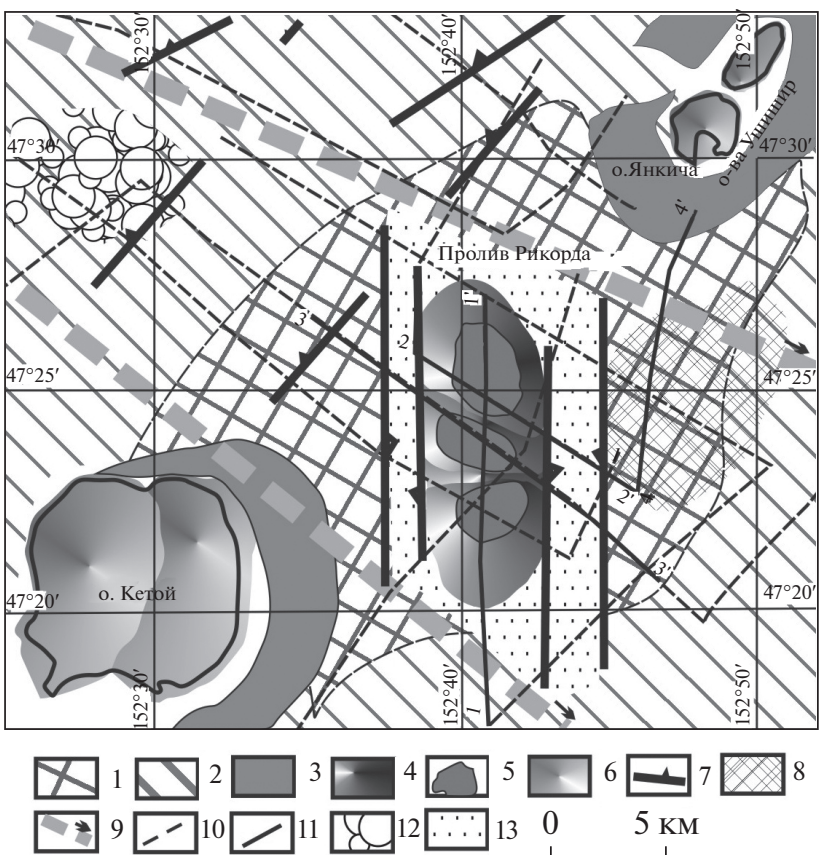

Рис. 1. Местоположение подводного вулканического массива Рикорда (а) и морфоструктурная схема пролива Рикорда (б). 1 - эрозионные и эрозионно-тектонические поверхности дна Курильских проливов; 2 - крутонаклонные $\left(>10^{\circ}\right)$ эрозионно-тектонические или эрозионно-вулканогенные поверхности дна верхней части склонов Большой Курильской гряды; 3 - плоские участки дна на глубинах до 140-160 м, соответствующих голоценовому повышению уровня моря; 4 - подводные вулканы; 5 - уплощенные вершины подводных вулканов; 6 - наземные вулканы; 7 - разломы, установленные по данным геофизических исследований; 8 - погребенные древние абразионные поверхности; 9 - предполагаемые зоны сбросо-сдвигов; 10 - геофизические профили; 11 - фрагменты профилей НСП, сейсмограммы по которым представлены на рис. 3 и 4; 12 - участки распространения оползневых отложений; 13 - грабен Рикорда.

\section{МОРФОСТРУКТУРА}

Подводные вулканы Центральных Курил, как правило, образуют цепочки разного направления и приурочены к предполагаемым, преимущественно правостронним, сбрососдвигам или к оперяющим их разломам. Зоны сбросо-сдвигов делят Центральные Курилы на четыре участка, различающиеся по особенностям морфоструктуры: о. Матуа - пр. Надежды, о. Расшуа - о-ва Ушишир, пр. Рикорда - пр. Дианы и район о. Симушир [Бондаренко, Рашидов, 2011a, 2011б].

В четвертичное время Центральные Курилы испытали значительное опускание с амплитудой от первых сотен метров до одного км.

Подножие подводного вулканического массива Рикорда располагается на глубинах 600-700 м, а плоская вершина, размером $2 \times 9$ км - на глубинах 130-150 м (см. рис. 1а, рис. 2a). Размер основания массива $9 \times 19 \mathrm{Kм}$, а объем - около $50 \mathrm{KM}^{3}$.

Северные, западные и восточные склоны массива очень крутые, до $20^{\circ}-30^{\circ}$. Южные склоны более пологие $-3^{\circ}-7^{\circ}$. Рельеф дна прилегающих к массиву участков неровный. Вероятно, это обусловлено активной эрозионной деятельностью течений, особенно приливно-отливных, скорость которых в проливе может достигать 1.5-4 узлов. В пределах массива выделены четыре сливающиеся по основанию вулканические постройки. От о-вов Ушишир подводный вулканический массив Рикорда отделяется участками дна с глубинами $600-700$ м, а от о. Кетой - с глубинами 350-400 м.

\section{СЕЙСМОАКУСТИЧЕСКИЕ ИССЛЕДОВАНИЯ}

Судя по характеру сейсмоакустического изображения, в строении массива принимают участие как плотные эффузивные породы, так и рыхлые, по-видимому, пирокластические и осадочные образования. Данные геофизических исследований позволяют выделить четыре сливающиеся по основанию постройки [Блох и др., 2013, 2017], сложенные, преимущественно, плотными вулканическими породами (рис. 3a, В.1-B.4).

При этом вулканы В.1, В.2, В.4 (см. рис. 3) имеют плоские вершины на глубине около 150 м. Между ними отмечаются небольшие (до 200 м) понижения в рельефе дна. Глубина плоских вершин вулканов соответствует уровню позднеплей- 
(a)

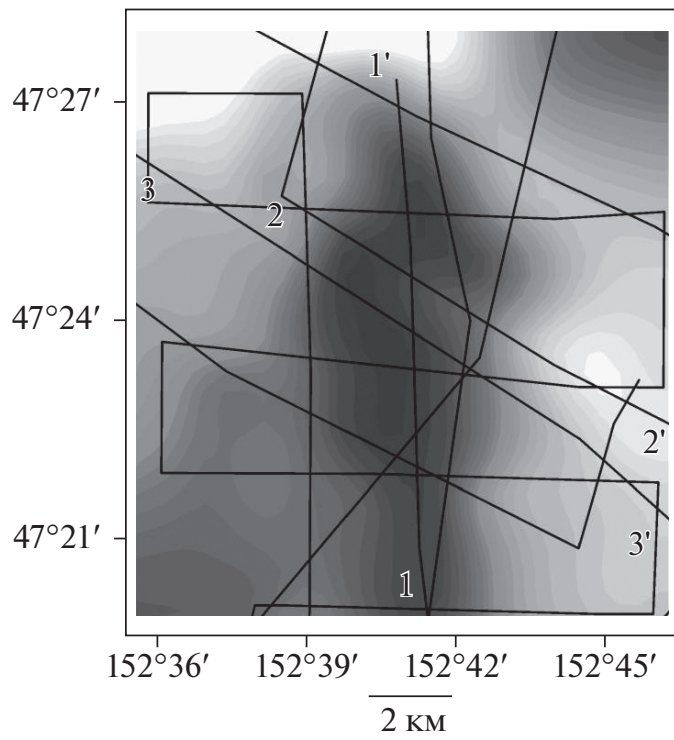

(в)

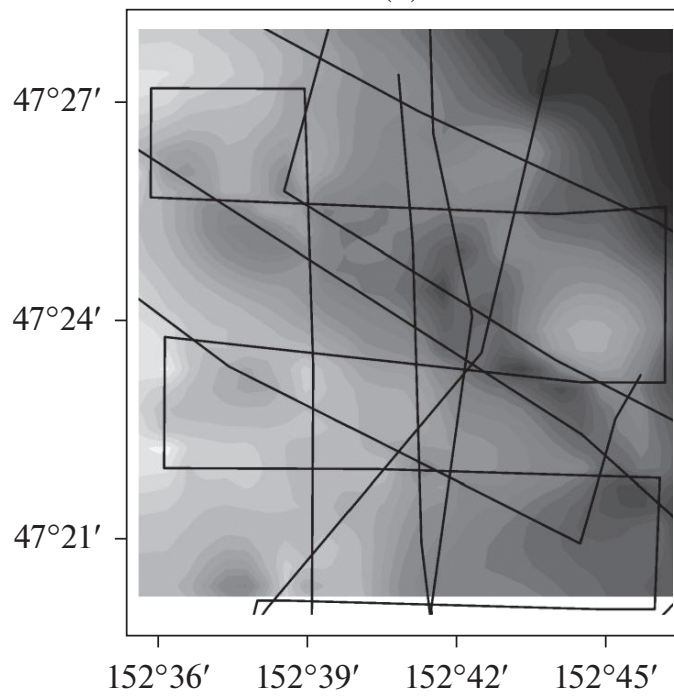

(б)

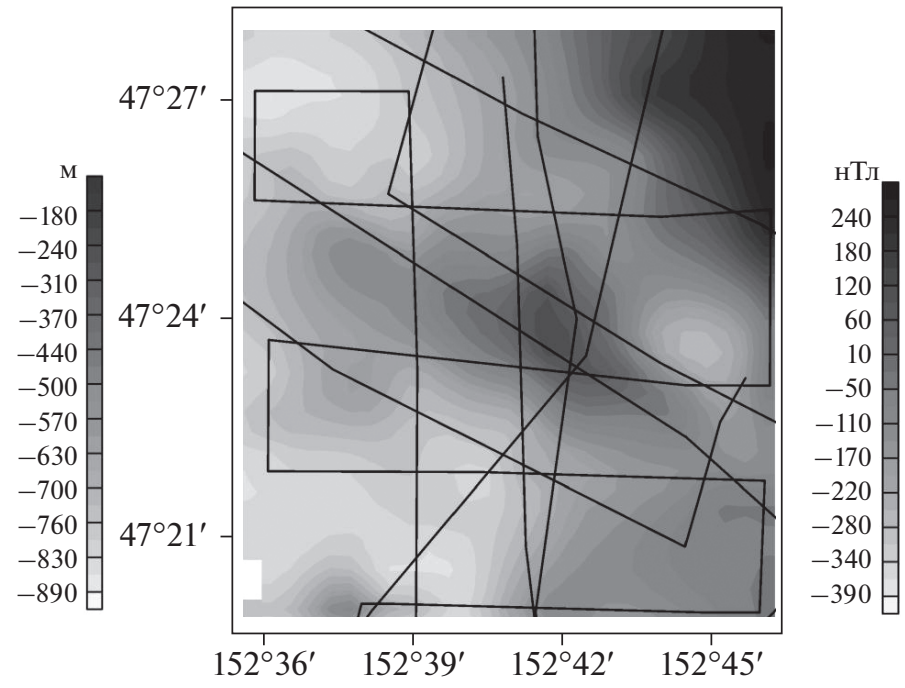

(г)

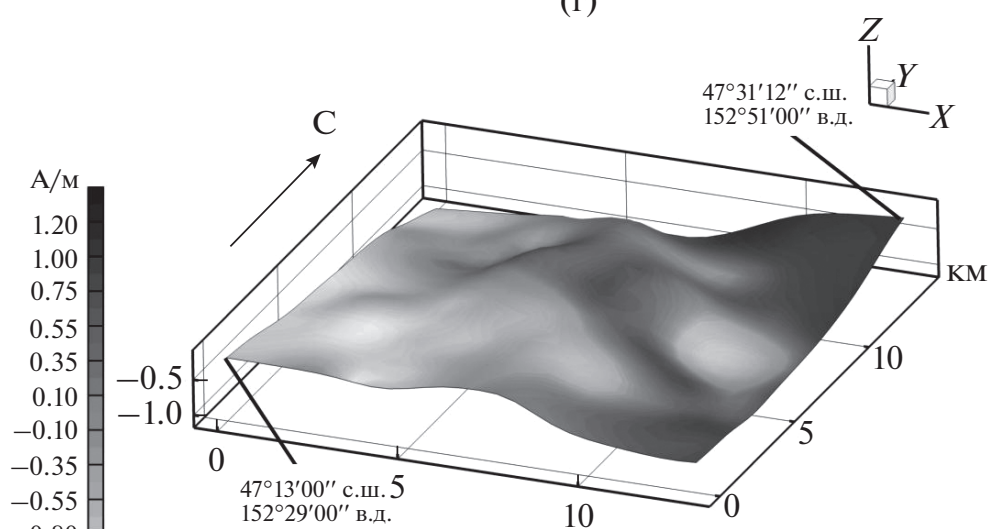

Рис. 2. Подводный вулканический массив Рикорда.

$\mathrm{a}$ - батиметрия; б - аномальное магнитное поле $\Delta \mathrm{T}_{\mathrm{a}}$; в - распределение эффективной намагниченности $\mathrm{J}_{\text {эф }}$ вулкана; г - распределение эффективной намагниченности $\mathbf{J}_{\text {эф}}$, изображенное на поверхности вулкана. Цифрами обозначены профили, приведенные на рис. 16,3 и 9.

стоценовой подводной террасы, сформировавшейся в результате значительного понижения уровня Охотского моря во время последнего оледенения [Безруков и др., 1958; Горшков, 1967; Камчатка ..., 1974]. Таким образом, мы можем предполагать доголоценовый возраст построек, слагающих массив Рикорда. Между вулканами В.1 и В.2 по данным НСП отмечается своеобразная толща сложно переслаивающихся отложений, характеризующихся многочисленными протяженными наклонными интенсивными отражающими границами (см. рис. 3a). Мощность их порядка $0.25-0.3$ с в масштабе удвоенного време- ни распространения сигнала (УВ), что может соответствовать 250-300 м при скорости звука 2000 м/с. Характер сейсмоакустического изображения разреза позволяет предполагать, что источником материала для формирования этой толщи являлись вулканы В.1 и В.2, при этом материал с обоих вулканов поступал синхронно. Вероятно, эти отложения сформировались в позднем плейстоцене в результате переотложения материала, образовавшегося при срезании вершин вулканов. Вулкан В.3 в настоящее время полностью погребен под осадочными отложениями, его вершина находится на глубинах 230-250 м. 
(a)

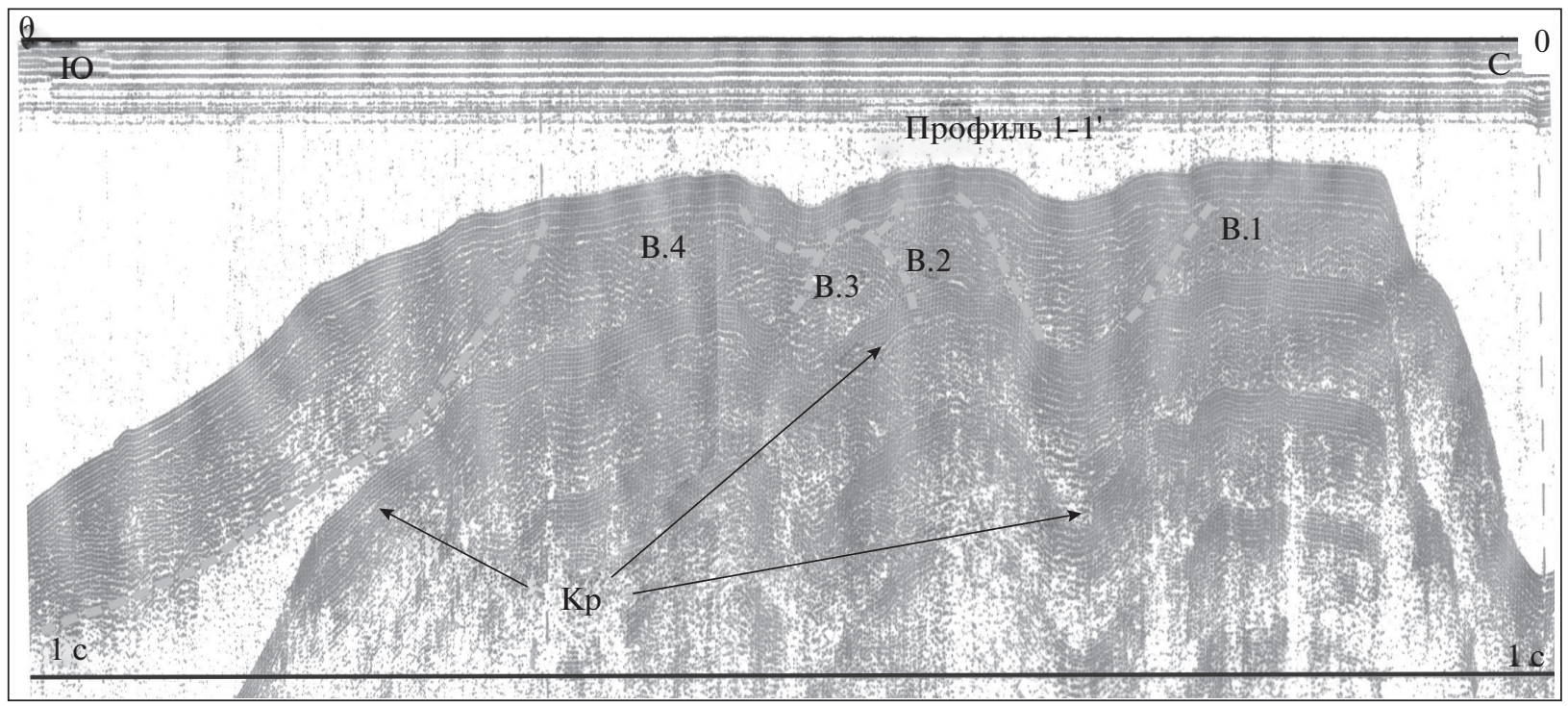

(б)

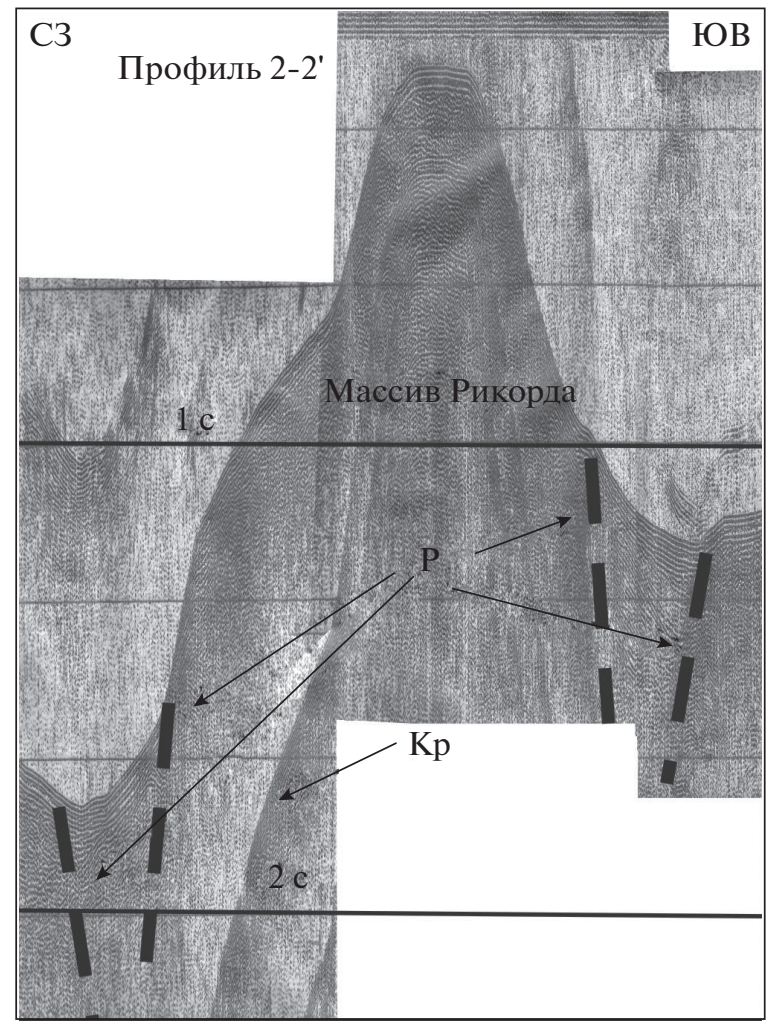

(в)

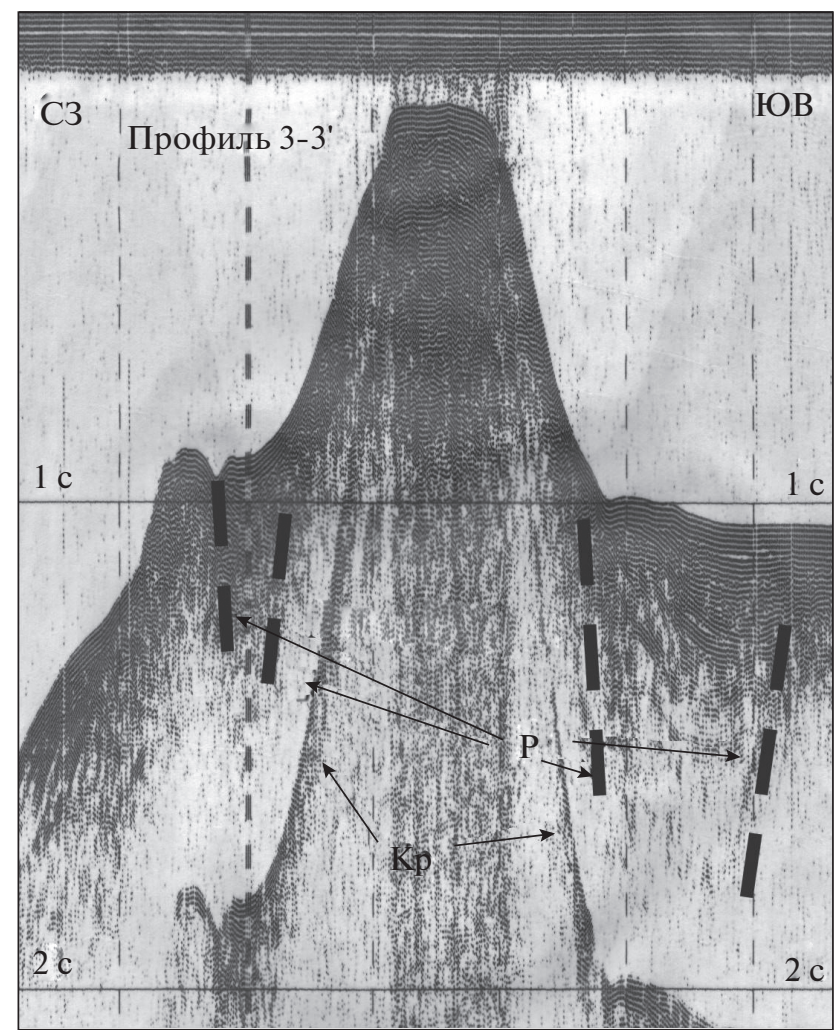

Рис. 3. Фрагменты сейсмограмм НСП по профилям 1-3. Кр - кратные отражения; Р - разломы; В.1, В.2 ... - вулканические постройки, слагающие массив Рикорда. Пространственное положение профилей представлено на рис. 16.

На южных относительно пологих склонах массива отчетливо дешифрируются клиноформы бокового наращивания с тангенциальной косой слоистостью (см. рис. За). Суммарная мощность этого комплекса от 0.3 с УВ в верхней части до 0.2 с УВ у подножия массива. Наблюдаемая картина свидетельствует о высокоэнергетической обстановке осадконакопления с интенсивным поступлением рыхлого материала, а также указывает на вулкан В.4 как главный источник материала. Ве- 
роятнее всего, этот материал также образовался в результате эрозии вершинной части массива Рикорда в позднем плейстоцене.

По данным НСП в проливе Рикорда отчетливо выделяется ряд разломов (см. рис. 16, 3). Особенности сейсмоакустического изображения разреза, рисунок выявленных в этом районе разломов, относительное расположение вершинных поверхностей Большой Курильской гряды на участке Расшуа-Ушишир и на участке от массива Рикорда до о. Симушир, позволяют предполагать наличие на границе этих участков крупных разломных зон (см. рис. 3) со сдвиговым характером смещений (вероятно, правосторонний сдвиг или сбросо-сдвиг) между о-вами Ушишир и подводным вулканическим массивом Рикорда и в южной части пролива, между массивом Рикорда и о. Кетой [Бондаренко, Рашидов, 2007]. Сам массив Рикорда располагается внутри субмеридиональной грабенообразной структуры, названной нами грабеном Рикорда. Возможно, образование грабена связано со сдвиговыми смещениями по упоминавшимся выше сдвиговым зонам по механизму формирования впадин типа пулл-апарт (pull-apart) [Прокопьев и др., 2004; Тевелев, Тевелев, 1996]. Растяжение земной коры при формировании грабена Рикорда, вероятно, привело к активизации магматизма и образованию подводного вулканического массива.

К востоку от массива Рикорда на профилях НСП отчетливо прослеживается слабо наклонная отражающая граница на глубинах 800-900 м (рис. 4). Ниже этой границы регулярные отражения на сейсмограммах НСП практически отсутствуют, при довольно высоком уровне записей нерегулярных сигналов. По-видимому, данная отражающая граница соответствует какой-то древней абразионной поверхности выравнивания, выработанной в вулканических породах.

В северном направлении непосредственно на эту поверхность налегает нижняя часть постройки вулканического массива Ушишир, сложенная, скорее всего, преимущественно рыхлыми отложениями [Бондаренко, Рашидов, 2007]. Мощность этих отложений быстро возрастает в сторону о. Янкича (см. рис. 4). Отчетливо фиксирующиеся на сейсмограммах НСП внутри этой толщи протяженные отражающие границы образуют расходящийся в сторону острова веер. Наблюдаемая картина указывает на то, что поступление материала при формировании данной толщи было не регулярным, и источник материала находился в районе о-вов Ушишир. Скорее всего, этим источником являлся действующий вулкан Ушишир. По существующим представлениям [Бондаренко, 1986, 2015; Горшков, 1967; Камчатка ..., 1974], возраст массива Ушишир - четвертичный. Поверхность, на которую ложится его основание, имеет более древний возраст - раннечетвертичный или позднеплиоценовый. Современное ее положение на глубине 800-900 м указывает на значительное погружение данной территории в четвертичное время - порядка 900 м.

С запада поверхность несогласия ограничивается грабеном Рикорда. Вероятно, этот грабен и массив Рикорда моложе этой абразионной поверхности, то есть имеют четвертичный возраст (возможно средний-поздний плейстоцен)

\section{ПЕТРОГРАФИЧЕСКИЕ ИССЛЕДОВАНИЯ}

В пределах привершинной части вулканического массива в 25 рейсе НИС “Вулканолог” была отработана одна драга в глубинном интервале 360-270 м на участке длиной около 1 км. При драгировании были подняты разнообразные породы, представленные, в основном, свежими угловатыми обломками [Блох и др., 2013, 2017; Подводный вулканизм ..., 1992]. По химическому составу драгированные породы представлены двумя различными сериями: относительно низко-кремнистой низко-калиевой, высоко-кальциевой базальтовой (в мас. \%: $\mathrm{SiO}_{2}=48-50, \mathrm{~K}_{2} \mathrm{O}=0.1-0.3, \mathrm{CaO}=$ $=10.5-11.5)$ и, присутствующей в подчиненном количестве, умерено- и высоко-кремнистой, умерено-калиевой и низко-карбонатной андезитовой $\left(\mathrm{SiO}_{2}=55-61, \mathrm{~K}_{2} \mathrm{O}=0.7-1.0, \mathrm{CaO}=6.5-8.5\right)$ [Подводный вулканизм ..., 1992]. Редко встречаются породы промежуточного андезибазальтового состава. В табл. 1 приведена краткая характеристика пород всех трех типов, а на рис. 5 показаны их структуры и минеральный состав.

Одной из главных особенностей минералогии пород, слагающих привершинную часть массива Рикорда, является присутствие в них редкого пироксена - пижонита. В андезитах по химическому составу четко выделяется три разновидности пироксена: авгит (Са 38 мол. \%), пижонит $(\mathrm{Ca} \sim 11$ мол. \%) и гиперстен (Ca $\sim 2-4$ мол. \%). В базальтах и андезибазальтах фиксируется наличие переходных составов от клинопироксена (пижонита) к ортопироксену (феррогиперстену-гиперстену). Сохранение в лавах пижонита, как самостоятельного минерала, возможно только в случае стремительного застывания породы. При этом состав пижонита сохраняется и соответствует первичным условиям равновесия в момент извержения [Дир и др., 1965]. Таким образом, совместное присутствие (парагенетическая ассоциация) оливина, пижонита и ортопироксена позволяет оценить температуру расплава в магматической камере порядка $1200-1300^{\circ} \mathrm{C}$ (температура кристаллизации и устойчивого существования пижонита).

Существование практически неразрывного ряда химического состава пород от базальтов до 
С

Ю

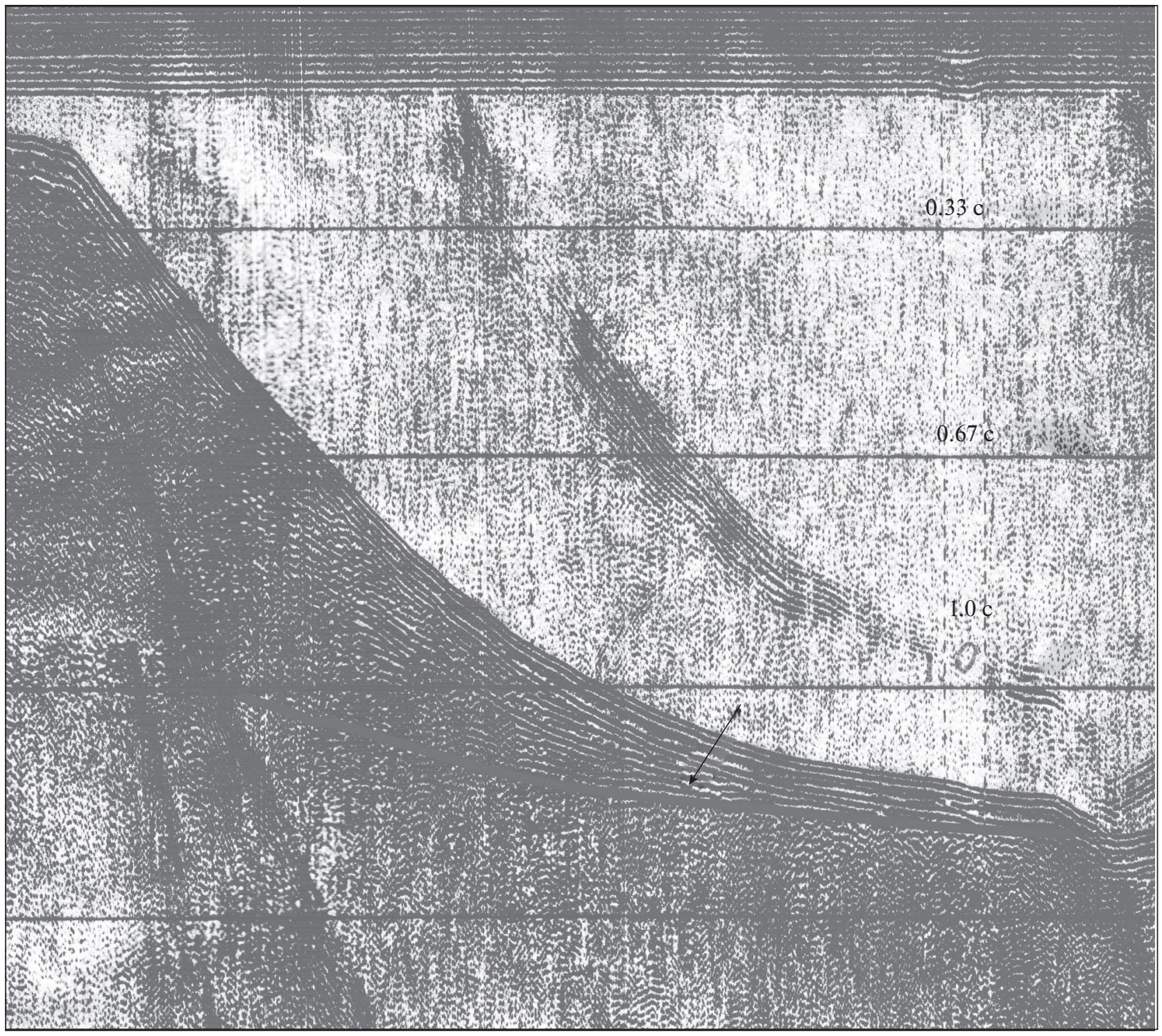

Рис. 4. Фрагмент сейсмограммы НСП по профилю 4. Стрелкой показана слабо наклонная отражающая граница. Положение профиля представлено на рис. 16.

андезитов, присутствие переходных разностей от андезина до битовнита и зональных кристаллов плагиоклаза, постепенная смена мафических минеральных ассоциаций на сиалические, свидетельствует о генетическом родстве драгированных образцов. Фактический материал позволяет предположить, что на начальных этапах жизни вулканического массива Рикорда изливались базальтовые и андезибазальтовые лавы.

По мере кристаллизации базальтов материнский расплав обеднялся мафическими компонентами и обогащался сиалическими. Результатом этой дифференциации стали излияния разных по- токов андезитов, характеризующихся переменным, постепенно уменьшающимся содержанием темноцветных минералов и увеличением количества плагиоклаза. При этом возникает ситуация, при которой состав вкрапленников плагиоклаза в андезитах не намного кислее, чем в базальтах. Вероятно, это происходит вследствие того, что в результате резкого уменьшения количества пироксена, расплав обогащается кальцием.

Можно предположить, что наиболее древние постройки массива Рикорда имеют базальтовый и андезибазальтовый состав, а наиболее молодые андезитовый. 
Таблица 1. Минеральный состав и структурные особенности пород, драгированных с привершинной части подводного вулканического массива Рикорда

\begin{tabular}{|c|c|c|c|c|}
\hline \multicolumn{2}{|c|}{ Свойства породы } & Базальт & Андезибазальт & Андезит \\
\hline \multirow[t]{2}{*}{ Структура } & Породы & \multicolumn{3}{|c|}{ Крупнопорфировая } \\
\hline & Основной массы & $\begin{array}{l}\text { Диабазовая, реже } \\
\text { трахитовая }\end{array}$ & $\begin{array}{l}\text { Микродолеритовая, } \\
\text { местами слабо тра- } \\
\text { хитовая, редко гиа- } \\
\text { лопелитовая или } \\
\text { интерсертальная }\end{array}$ & $\begin{array}{l}\text { Долеритовая, } \\
\text { местами слабо } \\
\text { трахитовая }\end{array}$ \\
\hline \multicolumn{2}{|c|}{ Отношение вкрапленники/основная масса } & от $3 / 5$ до $1 / 1$ & от $3 / 5$ до $1 / 3$ & $1 / 31 / 5$ \\
\hline \multicolumn{2}{|c|}{ Состав вкрапленников (\%) } & $\begin{array}{l}\text { Плагиоклаз (60-70), } \\
\text { моноклинный } \\
\text { пироксен }(10-25), \\
\text { оливин }(1-10), \\
\text { ромбический } \\
\text { пироксен }(0-3), \\
\text { титаномагнетит }(0)\end{array}$ & $\begin{array}{l}\text { Плагиоклаз }(70-80), \\
\text { моноклинный } \\
\text { пироксен }(7-15), \\
\text { оливин }(1-5, \text { редко } \\
10), \text { ромбический } \\
\text { пироксен }(0-3), \\
\text { титаномагнетит }(<1)\end{array}$ & $\begin{array}{l}\text { Плагиоклаз (85-99), } \\
\text { моноклинный } \\
\text { пироксен }(1-15), \\
\text { ромбический } \\
\text { пироксен }(0-5), \\
\text { оливин }(0-1), \text { тита- } \\
\text { номагнетит }(0-5)\end{array}$ \\
\hline \multicolumn{2}{|c|}{ Состав микролитов (\%) } & $\begin{array}{l}\text { Плагиоклаз (20-50), } \\
\text { моноклинный } \\
\text { пироксен }(20-40) \\
\text { титаномагнетит } \\
(20-40), \text { редко вул- } \\
\text { каническое стекло } \\
\text { и кварц в интерсти- } \\
\text { циях }\end{array}$ & $\begin{array}{l}\text { Пироксен ( 40), } \\
\text { титаномагнетит } \\
(\sim 40), \\
\text { плагиоклаз - } 20\end{array}$ & $\begin{array}{l}\text { Плагиоклаз (30-35), } \\
\text { пироксен (30-35) } \\
\text { титаномагнетит } \\
(30-40), \text { редко } \\
\text { кварц и интерсти- } \\
\text { ционное стекло }\end{array}$ \\
\hline \multicolumn{2}{|c|}{ Размер микролитов (мм) } & $0.01-0.1$ & $0.01-0.1$ & $0.01-0.1$ \\
\hline
\end{tabular}

Вкрапленники

\begin{tabular}{|c|c|c|c|c|}
\hline \multirow[t]{5}{*}{ Плагиоклаз } & Размер (мм) & $0.2-4$ & $0.1-0.2$ до 4 & $0.2-4.0$ \\
\hline & $\begin{array}{l}\text { Зональ- } \\
\text { ность }\end{array}$ & $2-4$ & $2-6$ & до 4 \\
\hline & Состав & $\begin{array}{l}\text { От битовнита } 89 \text { в } \\
\text { центре до лабрадора } \\
52 \text { по краям }\end{array}$ & $\begin{array}{l}\text { От битовнита до } \\
\text { лабрадора }\end{array}$ & $\begin{array}{l}\text { От битовнита } 85 \text { в } \\
\text { центре до андезина } \\
38-45 \text { по краям }\end{array}$ \\
\hline & Замещение & $\begin{array}{l}\text { Выщелачивание } \\
\text { центральных зон, } \\
\text { стекловатые ото- } \\
\text { рочки по зонам } \\
\text { роста }\end{array}$ & $\begin{array}{l}\text { Сдвойникованный, } \\
\text { насыщенный вклю- } \\
\text { чениями стекла }\end{array}$ & $\begin{array}{l}\text { Сдвойникованный, } \\
\text { сильно разбитый } \\
\text { трещинками, насы- } \\
\text { щенный включени- } \\
\text { ями стекла и иногда } \\
\text { раскристаллизован- } \\
\text { ной основной массы }\end{array}$ \\
\hline & Сростки & $\begin{array}{l}\text { Между плагиокла- } \\
\text { зами, с ромбиче- } \\
\text { ским пироксеном, } \\
\text { стеклом }\end{array}$ & $\begin{array}{l}\text { Некоторые внутрен- } \\
\text { ние зоны насы- } \\
\text { щены включениями } \\
\text { стекла (до 90\%) }\end{array}$ & Со стеклом \\
\hline
\end{tabular}


Таблица 1. Продолжение

\begin{tabular}{|c|c|c|c|c|}
\hline \multicolumn{2}{|c|}{ Свойства породы } & \multirow{2}{*}{$\begin{array}{c}\text { Базальт } \\
0.2-0.8, \text { редко до } 1.5\end{array}$} & \multirow{2}{*}{\begin{tabular}{|l|}
\multicolumn{1}{|c|}{ Андезибазальт } \\
Обычно до 0.1, \\
редко 0.2-0.8 до 1.5
\end{tabular}} & \multirow{2}{*}{\begin{tabular}{|r|} 
Андезит \\
$0.2-0.8$
\end{tabular}} \\
\hline Оливин & Размер & & & \\
\hline & Состав, мол. \% & $\begin{array}{l}\text { Fо от } 64.8 \text { до } 74.4 \text {, } \\
\text { или Fа от } 35.2 \text { до } \\
25.6\end{array}$ & Fo $60-70$ & Fo $60-70$ \\
\hline & Замещение & $\begin{array}{l}\text { По трещинам и } \\
\text { краям кристаллов } \\
\text { иддингситом и } \\
\text { боулингитом }\end{array}$ & Слабо изменен & $\begin{array}{l}\text { Почти полностью } \\
\text { выщелочен }\end{array}$ \\
\hline & Сростки & $\begin{array}{l}\text { С ромбическим и } \\
\text { моноклинным } \\
\text { пироксеном, вклю- } \\
\text { чения титаномагне- } \\
\text { тита }\end{array}$ & С титаномагнетитом & С титаномагнетитом \\
\hline \multirow{3}{*}{$\begin{array}{l}\text { Пироксен } \\
\text { моноклинный }\end{array}$} & Размер (мм) & $0.2-2.5$ & $0.1-4$ & $0.2-0.8$ \\
\hline & Состав, мол. \% & $\begin{array}{l}\mathrm{Mg} \text { - от } 40 \text { до } 50, \\
\mathrm{Ca}-\text { от } 29 \text { до } 41, \\
\mathrm{Fe}-\text { от } 18 \text { до } 24, \text { т.e } \\
\text { авгит и реже ферро- } \\
\text { авгит }\end{array}$ & Авгит & $\begin{array}{l}\mathrm{Mg}-42.8 \\
\mathrm{Ca}-38.1 \\
\mathrm{Fe}-19.1-\text { авгит } \\
\mathrm{Mg}-44.1 ; \\
\mathrm{Ca}-11.3 ; \\
\mathrm{Fe}-44.6 \text { - пижонит }\end{array}$ \\
\hline & Замещение & Не изменен & Не изменен & $\begin{array}{l}\text { Частично выщело- } \\
\text { чен }\end{array}$ \\
\hline Пижонит & Сростки & $\begin{array}{l}\text { С плагиоклазом, } \\
\text { оливином, ромбиче- } \\
\text { ским пироксеном }\end{array}$ & $\begin{array}{l}\text { С плагиоклазом, } \\
\text { титаномагнетитом }\end{array}$ & \\
\hline Пижонит & Размер (мм) & \multicolumn{3}{|l|}{$\leq 0.4$} \\
\hline \multirow[t]{3}{*}{$\begin{array}{l}\text { Пироксен } \\
\text { ромбический }\end{array}$} & Состав, мол. \% & $\begin{array}{l}\text { Мg от } 44 \text { до } 68, \\
\text { Fе от } 21 \text { до } 45, \\
\text { Са от } 2.6 \text { до } 12 \text {, т.е от } \\
\text { ферригиперстена до } \\
\text { гиперстена и пижо- } \\
\text { нита без перерывов }\end{array}$ & Гиперстен, пижонит & $\begin{array}{l}\mathrm{Mg}-64.6 ; \\
\mathrm{Ca}-3.5 ; \\
\mathrm{Fe}-31.8-\text { гипер- } \\
\text { стен } \\
\text { Перерыв в составе } \\
\text { между гиперстеном } \\
\text { и пижонитом }\end{array}$ \\
\hline & Замещение & Не изменен & Не изменен & Не изменен \\
\hline & Сростки & $\begin{array}{l}\text { Между собой, моно- } \\
\text { клинным пироксе- } \\
\text { ном, оливином, } \\
\text { плагиоклазом }\end{array}$ & $\begin{array}{l}\text { С оливином, пла- } \\
\text { гиоклазом }\end{array}$ & С плагиоклазом \\
\hline \multirow[t]{4}{*}{ Титаномагнетит } & Размер (мм) & Только микролиты & $0.1-1.0$ & $0.2-0.8$ \\
\hline & $\mathrm{K}$-во $\mathrm{Fe}^{\mathrm{II}}$ & $\begin{array}{l}0.65-0.68 \text { единиц в } \\
\text { формуле }\end{array}$ & $0.69-0.72$ & $0.72-0.74$ \\
\hline & $\mathrm{K}$-во $\mathrm{Fe}^{\mathrm{III}}$ & $1.44-1.49$ & $1.58-1.63$ & $1.53-1.59$ \\
\hline & К-во Ті & $0.36-0.44$ & $0.23-0.28$ & $0.27-0.31$ \\
\hline
\end{tabular}


Таблица 1. Окончание

\begin{tabular}{l|l|l|l|l}
\hline \multicolumn{2}{c|}{ Свойства породы } & \multicolumn{1}{c|}{ Базальт } & \multicolumn{1}{c}{ Андезибазальт } & \multicolumn{1}{c}{ Андезит } \\
\hline $\begin{array}{l}\text { Интерстицион- } \\
\text { ное стекло }\end{array}$ & Химический состав & Не встречено & Не встречено & $\mathrm{SiO}_{2}=72.32$ до 81.9; \\
& & & $\mathrm{TiO}_{2}=0.5-1.12 ;$ \\
& & & $\mathrm{Al}_{2} \mathrm{O}_{3}=11.8-12.22 ;$ \\
& & & $\mathrm{FeO}=0.7-2.67 ;$ \\
& & & & $\mathrm{CaO}=2.76-3.2 ;$ \\
& & & & $\mathrm{Na}_{2} \mathrm{O}=3.15-3.56 ;$ \\
& & & $\mathrm{K}_{2} \mathrm{O}=0.5-3.64$ \\
\hline
\end{tabular}

\section{ПЕТРОМАГНИТНЫЕ ИССЛЕДОВАНИЯ}

Первоначальные петромагнитные исследования показали, что среди драгированных пород наиболее магнитными оказались базальты, естественная остаточная намагниченность $\mathrm{J}_{\mathrm{n}}$ которых достигает 10 A/м, а наименее магнитными - андезиты, J которых не превышает 0.6 А/м [Блох и др., 2013].
В настоящей работе для выяснения основных носителей $\mathbf{J}_{\mathrm{n}}$ в горных породах, слагающих вулканический массив Рикорда, по отработанной методике [Рашидов и др., 2014, 2015, 2016] были выполнены комплексные петромагнитные исследования 8 образцов. Для измерения использовались кубики с ребром 1 см.
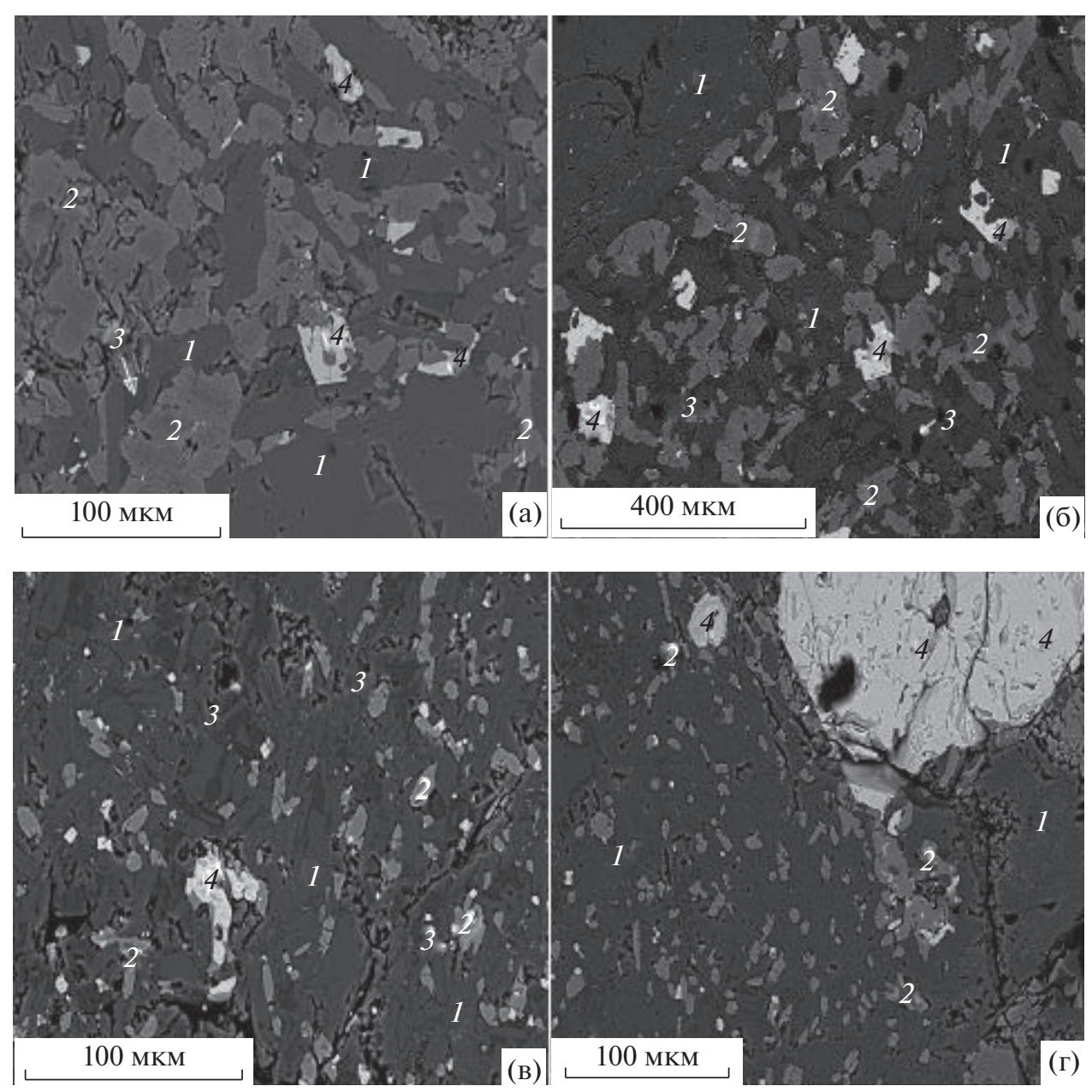

Рис. 5. Структуры базальта обр. В25-32/3 (а, б), и андезита обр. В25-32/9 (в, г).

1 - плагиоклаз; 2 - моноклинный пироксен; 3 - вулканическое стекло или кварц; 4 - титаномагнетит. 
(a)

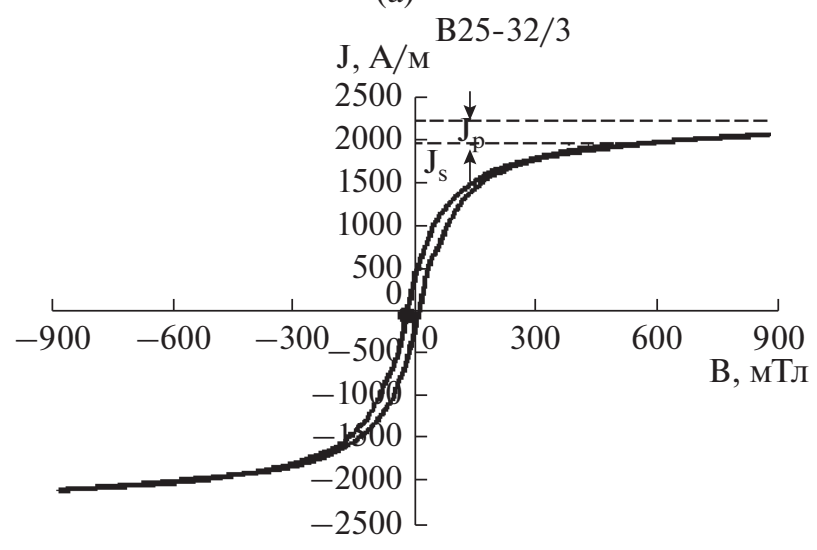

(б)

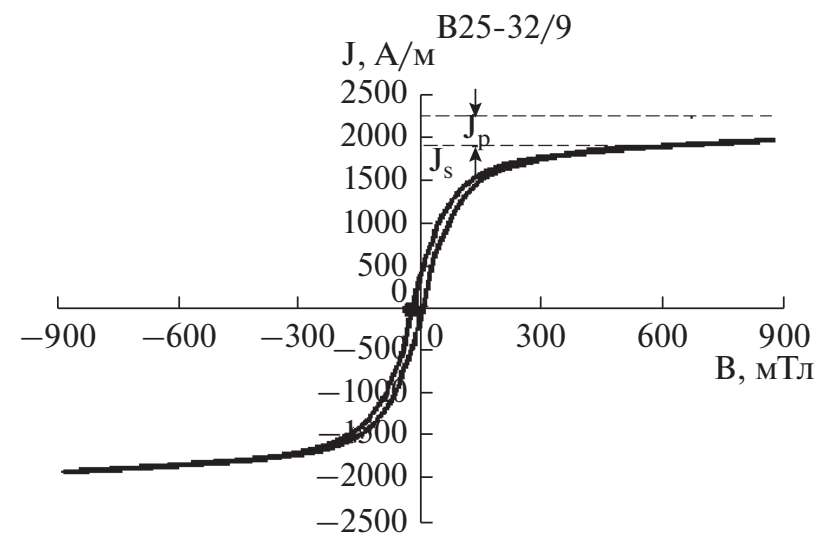

Рис. 6. Пример кривых магнитного гистерезиса в образцах, в которых основной носитель намагниченности являются магнетит (а) и титаномаггемит (б). $\mathbf{J}_{\mathrm{p}}-$ петромагнитный вклад в намагниченность; $\mathrm{J}_{\mathrm{s}}{ }$ намагниченность насыщения.

Измерения $\mathrm{J}_{\mathrm{n}}$ образцов проведены на магнитометре JR-6 (AGICO, Чехия) в трех ортогональных положениях вращения образца. Магнитная восприимчивость æ и степень анизотропии магнитной восприимчивости $\mathrm{P}^{\prime}$ определялась на каппаметре Multi-Function Kappabridge (AGICO, Чехия).

Для каждого образца были сняты кривые магнитного гистерезиса (рис. 6) на вибромагнитометре (ОРИОН, Россия), по которым проведена оценка доменного состояния по величине отношений $\mathrm{J}_{\mathrm{rs}} / \mathrm{J}_{\mathrm{s}}$ и $\mathrm{B}_{\mathrm{cr}} / \mathrm{B}_{\mathrm{c}}$ [Day et al., 1977] (рис. 7a). Магнитные параметры по кривым магнитного гистерезиса (табл. 2) определены с коррекцией на величину парамагнитного фона $\left(\mathrm{J}_{\mathrm{p}}\right)$.

Выполнены исследования состава ферромагнитной фракции путем проведения термомагнитного анализа (ТМА) по зависимости остаточной намагниченности насыщения $\mathbf{J}_{\mathrm{rs}}$ от температуры
$\mathrm{T}$ на двухкомпонентном термомагнитометре (ОРИОН, Россия) в атмосфере воздуха.

Петромагнитные исследования образцов базальтов (образцы В25-32/3, В25-32/4, В25-32/5, В25-32/11, В25-32/12) и андезибазальта (образец В25-32/1), показали, что высокие значения $\mathbf{J}_{\mathrm{n}}=$ =2-9 А/м обусловлены большим содержанием $\left(æ=(9-23) \times 10^{-3}\right.$ СИ) однодоменных и псевдооднодоменных зерен (SD-PSD) низкокоэрцитивных $\left(\mathrm{B}_{\mathrm{cr}}=18-23\right.$ мТл) ферромагнитных минералов. Образцы обладают низкой степенью магнитной анизотропии (см. табл. 2).

Относительно низкие значения $\mathrm{J}_{\mathrm{n}}=0.2-0.9 \mathrm{~A} / \mathrm{M}$ андезибазальта (образец В25-32/16) и андезита (образец В25-32/9) обусловлены большим содержанием $\left(æ=(15-33) \times 10^{-3}\right.$ СИ) псевдооднодоменных и многодоменных зерен (PSD-MD) низкокоэрцитивных ( $\mathrm{B}_{\mathrm{cr}}=12-23$ мТл) ферромагнитных минералов. Образцы также обладают низкой степенью магнитной анизотропии (см. табл. 2).

Исследованные образцы пород по поведению кривых термомагнитного анализа $\mathrm{J}_{\mathrm{rs}}(\mathrm{T})$ также можно разбить на две группы.

В первую группу попали образцы базальтов (образцы В25-32/3, В25-32/4, B25-32/11, B25-32/12) и андезибазальтов (образцы В25-32/1, В25-32/16). ТМА показал, что кривые первого нагрева имеют точку перегиба в интервале $\sim 490-575^{\circ} \mathrm{C}$ (см. рис. 7б). Кривые второго нагрева проходят выше, необратимы и имеют перегиб $\sim 575^{\circ} \mathrm{C}$. В этих образцах основным носителем намагниченности является титаномагнетит с низким содержанием Тi, по составу близкий к магнетиту. Высокие точки Кюри связаны с тем, что, возможно, титаномагнетит еще в природных условиях претерпел высокотемпературное окисление и распался на фазу, близкую к магнетиту, и гемоильминит. Рост намагниченности после прогрева до $600^{\circ} \mathrm{C}$ и последующего охлаждения связан с дальнейшим протеканием гетерофазного разложения титаномагнетита.

Количество Тi, полученное на основе микрозондового анализа микролитов и вкрапленников образов базальтов B25-32/3 и В25-32/11 и образца андезибазальта В25-32/16 дает значительно более низкие точки Кюри, что говорит о наличии титаномаггемита. Это еще раз подтверждает, что реальные океанические базальты всегда содержат несколько ферримагнитных фаз: титаномагнетит, а также продукты его однофазного и (или) гетерофазного окисления [Природа ..., 1996].

Во вторую группу по поведению кривых ТМА попали образцы базальта (B25-32/5) и андезита (B25-32/9). Кривая первого нагрева имеет точку перегиба в районе $380-420^{\circ}$ (см. рис. 7в). Кривая второго нагрева также проходит много выше, необратима и имеет перегиб в точке $\sim 575^{\circ} \mathrm{C}$. В этих образцах основным носителем намагниченности 


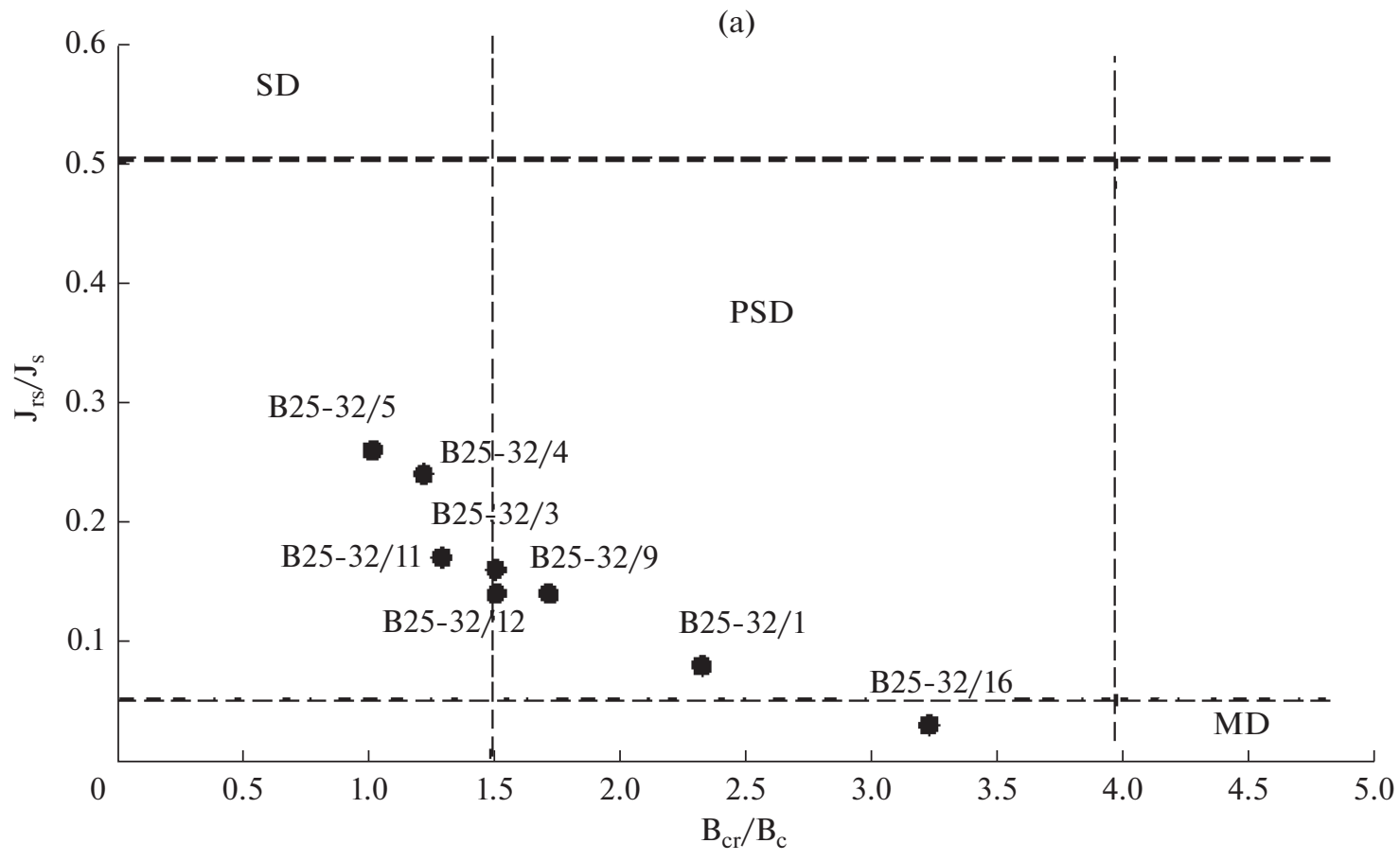

(б)

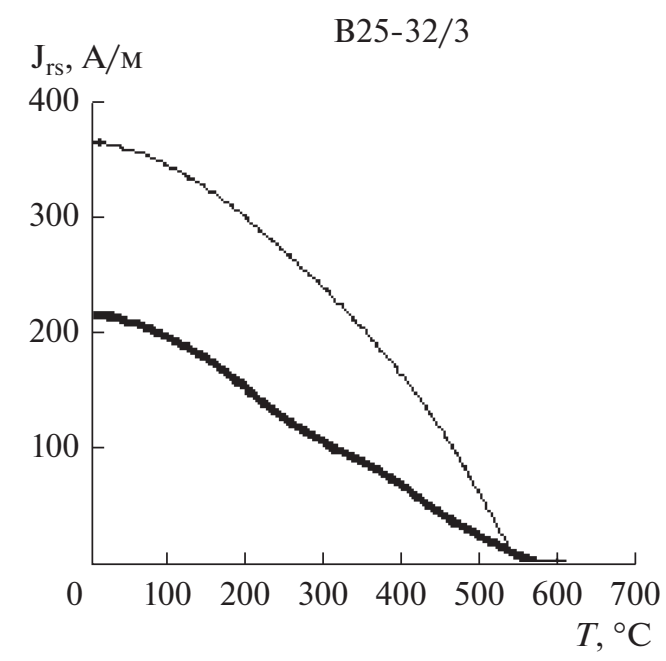

(в)

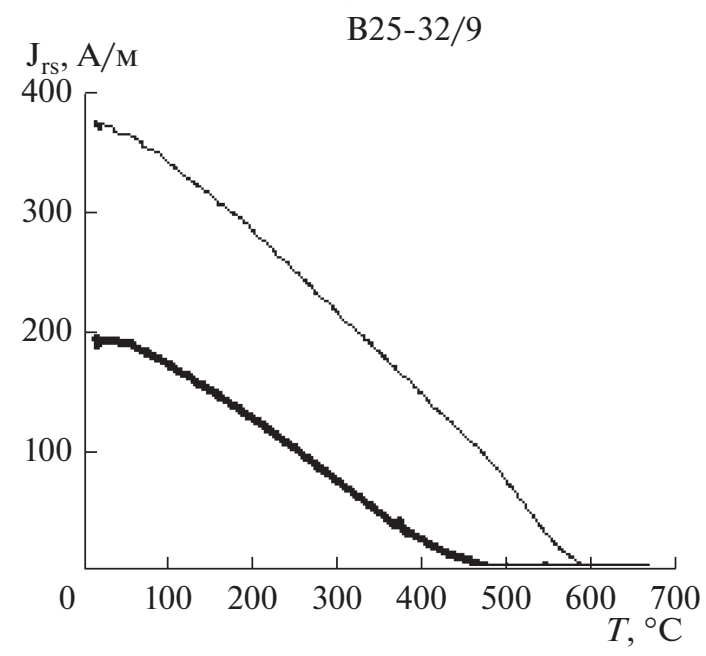

Рис. 7. Диаграмма Дэя (а) и кривые термомагнитного анализа $\mathrm{J}_{\mathrm{rs}}(\mathrm{T})$ образцов, основным носителем которых является магнетит (б) и титаномаггемит (в).

мог бы быть титаномагнетит с содержанием Ті X $\sim 0.22-0.28$ или титаномаггемит. Рост намагниченности после прогрева до $600^{\circ} \mathrm{C}$ и последующего охлаждения связан с протеканием гетерофазного разложения титаномагнетита (или титаномаггемита).

Микрозондовый анализ показал, что в микролитах образца андезита В25-32/9 (см. рис. 5в, г) содержание $\mathrm{Ti}(\mathrm{X} \sim 0.27-0.31)$, что соответствует расчетным точкам Кюри $\sim 350-380^{\circ} \mathrm{C}$, которые несколько ниже экспериментально обнаруженных. В этом образце основным носителем намаг- ниченности является однофазно окисленный титаномагнетит. Это соответствует выводу анализа химического состава титаномагнетита о том, что титаномагнетит возможно окислен.

При драгировании базальтов обычно преобладают образцы из краевых частей лавового потока [Природа ..., 1996]. Во внешних частях лавового потока процесс кристаллизации шел весьма быстро. Для них характерна однодоменная и псевдооднодоменная структура ферримагнитных зерен. О стремительном застывании лавы свидетельствует наличие в породе пижонита. Включе- 
Таблица 2. Петромагнитные характеристики горных пород, слагающих подводный вулканический массив Рикорда

\begin{tabular}{|c|c|c|c|c|c|c|c|c|c|c|c|c|c|c|c|}
\hline № & Образцы & Порода & $\begin{array}{c}J_{n}, \\
A / M\end{array}$ & $\begin{array}{c}æ, 10^{-3}, \\
\text { СИ }\end{array}$ & $\mathrm{Q}_{\mathrm{n}}$ & $\mathrm{P}^{\prime}$ & $\begin{array}{l}\mathrm{B}_{0.5} \text {, } \\
\text { мТл }\end{array}$ & $\begin{array}{c}\mathrm{J}_{\mathrm{rs}}, \\
\mathrm{A} / \mathrm{M}\end{array}$ & $\begin{array}{c}\mathrm{J}_{\mathrm{s}}, \\
\mathrm{A} / \mathrm{M}\end{array}$ & $\mathrm{J}_{\mathrm{rs}} / \mathrm{J}_{\mathrm{s}}$ & $\begin{array}{l}\mathrm{B}_{\mathrm{cr}}, \\
\mathrm{мTл}\end{array}$ & $\begin{array}{l}\mathrm{B}_{\mathrm{c}} \\
\text { мТл }\end{array}$ & $\mathrm{B}_{\mathrm{cr}} / \mathrm{B}_{\mathrm{c}}$ & Структура & C, \\
\hline 1 & B25-32/1-1 & & 2.35 & 17.88 & 3.30 & 1.030 & - & 175.0 & 2120 & 0.08 & 18 & 7.70 & 2.34 & PSD & 0.47 \\
\hline 2 & $25-32 / 1-2$ & & 2.74 & & & & 49 & & & & & & & & \\
\hline 3 & B25-32/3-1 & Базальт & 3.96 & 11.81 & 8.42 & 1.032 & - & 301.6 & 1890 & 0.16 & 22 & 14.50 & 1.52 & PSD & 0.42 \\
\hline 4 & B25-32/3-2 & & 3.50 & & & & 29 & & & & & & & & \\
\hline 5 & B25-32/4-1 & Базальт & 3.51 & 12.51 & 7.05 & 1.058 & - & 518.3 & 2175 & 0.24 & 22 & 17.88 & 1.23 & PSD (SD) & 0.4 \\
\hline 6 & B25-32/4-2 & & 3.41 & & & & 29 & & & & & & & & \\
\hline 7 & B25-32/5-1 & Базальт & 5.99 & 9.07 & 16.60 & 1.056 & - & 413.3 & 1620 & 0.26 & 18 & 17.50 & 1.03 & PSD (SD) & 0.4 \\
\hline 8 & B25-32/5-2 & & 5.86 & & & & 55 & & & & & & & & \\
\hline 9 & B25-32/9-1 & Андезит & 0.87 & 14.57 & 1.50 & 1.036 & - & 259.6 & 1800 & 0.14 & 23 & 13.30 & 1.73 & PSD & 0.4 \\
\hline 10 & B25-32/9-2 & & 0.65 & & & & 97 & & & & & & & & \\
\hline 11 & B25-32/11-1 & Базальт & 5.32 & 13.67 & 9.78 & 1.024 & - & 449.1 & 2650 & 0.17 & 23 & 17.65 & 1.30 & PSD (SD) & 0.5 \\
\hline 12 & B25-32/11-2 & & 5.25 & & & & 28 & & & & & & & & \\
\hline 13 & B25-32/12-1 & Плагио- & 8.57 & 22.94 & 9.39 & 1.021 & & 567.7 & 3950 & 0.14 & 19 & 12.50 & 1.52 & PSD & 0.8 \\
\hline 14 & B25-32/12-2 & & 7.80 & & & & 80 & & & & & & & & \\
\hline 15 & B25-32/16-1 & Андезит & 0.21 & 33.47 & 0.16 & 1.009 & - & 114.0 & 3475 & 0.03 & 12 & 3.70 & 3.24 & PSD (MD) & 0.7 \\
\hline 16 & B25-32/16-2 & & 0.14 & & & & 8 & & & & & & & & \\
\hline
\end{tabular}

Примечание. $\mathrm{J}_{\mathrm{n}}$ - естественная остаточная намагниченность; æ- магнитная восприимчивость; $\mathrm{Q}_{\mathrm{n}}-$ фактор Кенигсбергера; $\mathrm{P}^{\prime}$ - степень анизотропии магнитной восприимчивости; $\mathrm{B}_{0.5}$ - медианное поле; $\mathrm{J}_{\mathrm{rs}}$ - остаточная намагниченность насыщения; $\mathrm{J}_{\mathrm{s}}$ - намагниченность насыщения; $\mathrm{B}_{\mathrm{cr}}$ - остаточная коэрцитивная сила; $\mathrm{B}_{\mathrm{c}}-$ коэрцитивная сила; MD - многодоменные зерна; PSD - псевдооднодоменные зерна; SD - однодоменные зерна; C - объемная концентрация ферромагнетика.

ния титаномагнетита в кристаллы оливина говорит о том, что в данной породе кристаллизация титаномагнетита происходила на ранних стадиях формирования породы.

Фактор Кенигсбергера у всех образцов базальтов лежит в интервале $1.5-16.6$, то есть значительно превышает 1. Это подтверждает предположение о том, что базальты являются основным источником наблюдаемых магнитных аномалий, создаваемых подводным вулканическим массивом Рикорда.

\section{ГЕОМАГНИТНЫЕ ИССЛЕДОВАНИЯ}

Аномальное магнитное поле $\Delta \mathrm{T}_{\text {a }}$ подводного вулканического массива Рикорда имеет сложный мозаичный характер, который косвенно подтверждает его образование из нескольких вулканических конусов. Интенсивность магнитных аномалий в пределах массива изменяется в диапазоне $(-500 \ldots+1000)$ нТл (см. рис. 2б).

Интерпретация материалов геомагнитных исследований была выполнена с помощью разработанной авторами технологии моделирования данных ГМС в комплексе с эхолотным промером, НСП и анализом естественной остаточной на- магниченности $\mathbf{J}_{\mathrm{n}}$ и химического состава драгированных горных пород [Блох и др., 2012]. При этом применялись разнообразные методы интерпретации, одни из которых ориентированы на 2D и 2.5D-анализ магнитного поля на отдельных галсах, а другие - на 3D-анализ по всему массиву наблюдений. При расчетах использовался истинный рельеф вулканических построек, с учетом погребенного под осадками основания, полученный по данным эхолотного промера и НСП. Для уточнения глубинного строения подводных вулканов использовался метод особых точек, интерпретационная томография и монтажный метод решения обратной задачи магниторазведки (О3M).

С помощью программы ИГЛА [Блох и др., 2015, 2017; Блох, Трусов, 2007] уточнено, что вектор эффективной намагниченности пород отклонен от вектора нормального поля $\mathbf{T}_{\mathbf{0}}$ к юго-западу на угол около $80^{\circ}$. Эта программа реализует решение линейной обратной задачи в многоугольном интерпретационном окне, используя интерактивно подбираемую модель в виде усеченной пирамиды. На рис. 8 показаны исходные точки измерения магнитного поля и подобранная модель, дополнительно показано распределение намаг- 


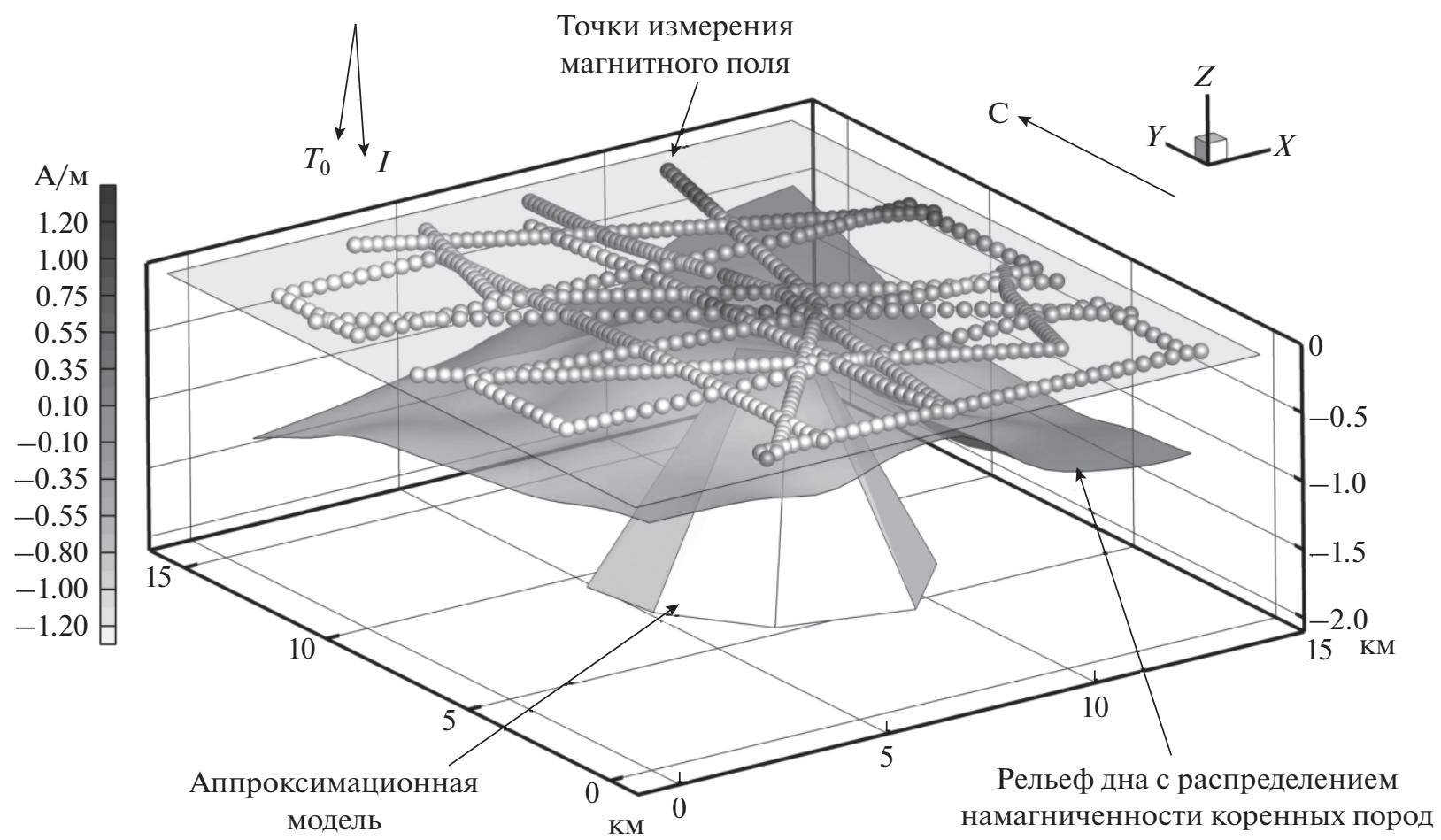

Рис. 8. Уточнение направления вектора намагниченности подводного вулканического массива Рикорда с помощью программы ИГЛА.

ниченности коренных пород, построенное с помощью программы REIST.

Такое направление вектора намагниченности достаточно характерно для пород подводных вулканов центральной части Курильской островной дуги, а его изменения в пределах региона свидетельствуют о приуроченности времени образования подводных вулканов к периодам геомагнитных инверсий [Блох и др., 2015]. Имеющиеся определения абсолютного возраста вулканических пород Центральных Курил относятся к интервалу от 620 тысяч примерно до 3.3 млн лет [Леликов, Емельянова, 2007; Ishizuka et al., 2011]. При этом надо подчеркнуть, что возраст образца, отобранного японскими учеными неподалеку от изучаемого подводного вулканического массива, на о-вах Ушишир, оказался равным 1.17 Ma [Ishizuka et al., 2011]. Следовательно, можно предположить, что формирование вулканического массива Рикорда происходило во время последней геомагнитной инверсии Матуяма-Брюнес.

Анализ особых точек функций, описывающих аномальные поля на отдельных галсах, проводился с помощью интегрированной системы СИНГУЛЯР [Блох и др., 1993], в которой реализованы известные методы В.Н. Страхова, В.М. Березкина и Г.А. Трошкова. Полученные результаты показали приуроченность основных особенностей функций, описывающих аномальные поля, к верхней кромке вулканических пород (рис. 9) и подтвердили наличие четырех вулканических построек, выделенных по данным НСП.

Помимо этого, характер вертикальных распределений локализованных особых точек позволил предположить субвертикальное, юго-западное и юго-юго-восточное направления подводящих каналов и наличие на глубине 2 км периферических магматических очагов.

Трехмерное моделирование вулканической постройки с помощью программы REIST из пакета структурной интерпретации гравитационных и магнитных аномалий СИГМА-3D [Бабаянц и др., 2004, 2005] показало, что максимальная эффективная намагниченность вулканического массива Рикорда достигает 0.7 А/м (см. рис. 2в, г). При этом среднеквадратическая погрешность подбора аномального магнитного поля после 70 итераций составила 30 нТл.

Томографический анализ подводного массива Рикорда отражает мозаичный характер аномального магнитного поля [Блох и др., 2013]. Главной тенденцией в распределении эффективной намагниченности является объединение нескольких локальных зон с увеличением эффективной глубины. Особо выделяются две положительные

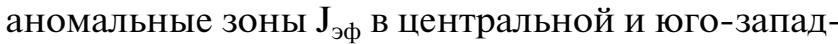
ной частях массива, прослеживающиеся до глубины 5-6 км. 

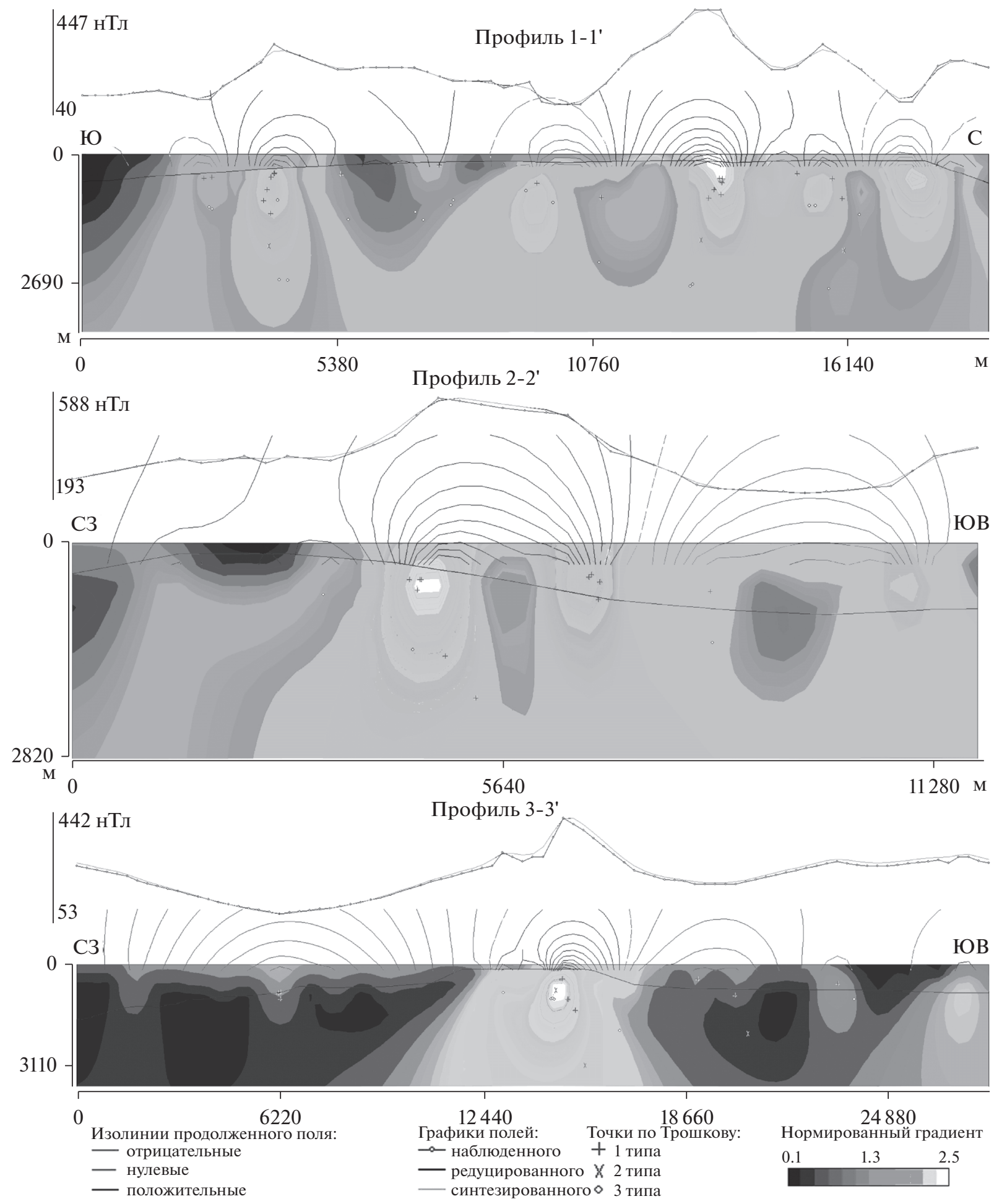

Рис. 9. Изображение, синтезированное системой СИНГУЛЯР, для локализации особых точек функции, описывающей аномальное магнитное поле $\Delta \mathrm{T}_{\mathrm{a}}$ подводного вулканического массива Рикорда, наложенное на рельеф дна. Положение профилей представлено на рис. 16 и 2. 

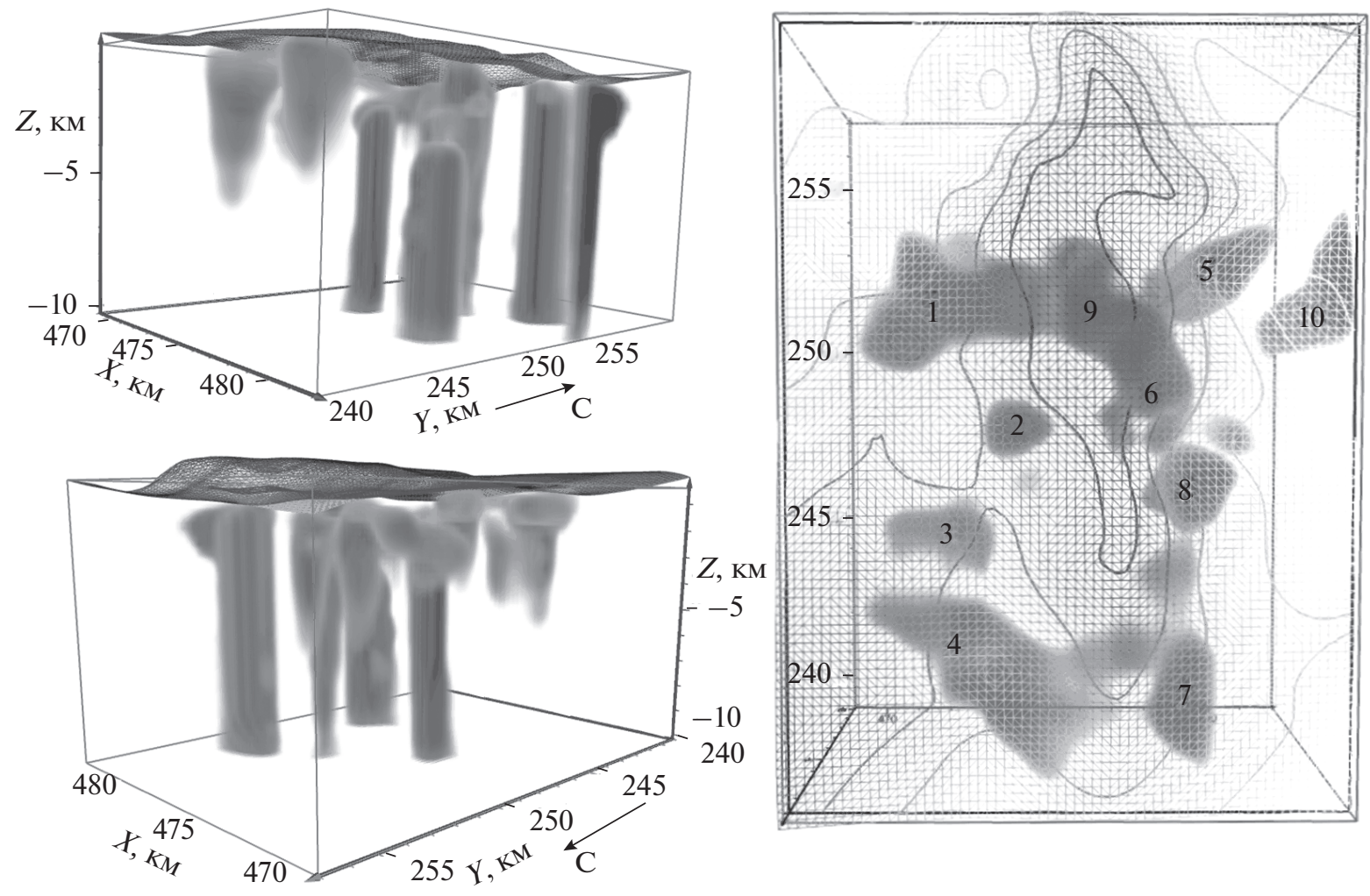

Рис. 10. Объемная геомагнитная модель центральной части подводного вулканического массива Рикорда. Цифрами

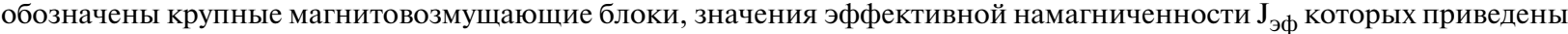
в табл. 3.

Решение смешанной ОЗМ монтажным методом позволило построить объемную модель центральной части вулканического массива и выделить здесь 10 крупных магнитовозмущающих блоков (рис. 10, табл. 3) с эффективной намагниченностью, изменяющейся в диапазоне $1-2$ А/м, которые мы связываем с застывшими подводящими каналами. Стоит отметить, что источниками большинства магнитных аномалий являются несколько сближенных объектов.

По направлению вектора намагниченности блоки можно условно разделить на две группы: с углом отклонения от вертикали от $2^{\circ}$ до $11^{\circ}$ и от $14^{\circ}$ до $23^{\circ}$ предположительно, направленные на Ю3 и ЮЮВ, что хорошо совпадает с результата- ми анализа магнитного поля с помощью программы ИГЛА. Это может свидетельствовать о приуроченности времени образования магнитовозмущающих блоков к периоду геомагнитной инверсии, когда намагничивающее поле Земли быстро меняло свое направление.

Глубина залегания верхней кромки большинства выделенных объектов соответствует рельефу вулканического массива, сами объекты распространяются до глубин от 5.4 до 10 км ниже уровня моря.

Сопоставляя результаты геомагнитного моделирования с данными петрологических и петромагнитных исследований можно предположить, что в вулканический массив Рикорда сложен, в

Таблица 3. Эффективная намагниченность $\mathbf{J}_{\text {эфф }}$ аномалиеобразующих тел

\begin{tabular}{l|c|c|c|c|c|c|c|c|c|c}
\hline \multicolumn{1}{c|}{ № тела } & 1 & 2 & 3 & 4 & 5 & 6 & 7 & 8 & 9 & 10 \\
\hline \multicolumn{1}{c|}{$\mathrm{J}_{\text {эфф}}, \mathrm{A} / \mathrm{M}$} & 1.4 & 1.7 & 1 & 1.6 & 1.3 & 1 & 1.7 & 1.3 & 2 & 1.1 \\
\hline $\begin{array}{l}\text { Угол намагниченности } \\
\text { (отклонение от вертикали) } \mathrm{J}_{\text {эфф}},{ }^{\circ} \\
\begin{array}{l}\text { Максимальная глубина распростра- } \\
\text { нения, км }\end{array}\end{array}$ & 14 & 11 & 23 & 5 & 11 & 20 & 2 & 10 & 20 & 10 \\
\hline
\end{tabular}


основном, породами эффузивного ряда от базальтов до андезитов.

\section{ЗАКЛЮЧЕНИЕ}

В результате выполненных исследований установлено, что вулканический массив Рикорда состоит из четырех сливающихся по основанию вулканических построек и, скорее всего, имеет четвертичный возраст (средний - поздний плейстоцен, возможно конец калабрия, когда проходила инверсия геомагнитного поля МатуямаБрюнес). В проливе Рикорда выделен ряд разломов, а сам массив Рикорда располагается внутри субмеридионального грабена Рикорда.

Существование практически неразрывного ряда химического состава драгированных пород от базальтов до андезитов, присутствие переходных разностей от андезина до битовнита и зональных кристаллов плагиоклаза, постепенная смена мафических минеральных ассоциаций на сиалические, свидетельствует о генетическом родстве драгированных образцов и позволяет предположить, что на начальных этапах жизни вулканического массива Рикорда изливались базальтовые и андезибазальтовые лавы. Температура расплава достигала $\sim 1200-1300^{\circ} \mathrm{C}$. По мере кристаллизации базальтов материнский расплав обеднялся мафическими компонентами и обогащался сиалическими. Результатом этой дифференциации стали излияния разных потоков андезитов.

Высокие значения естественной остаточной намагниченности драгированных горных пород обусловлены большим содержанием однодоменным и псевдооднодоменным зерен титаномагнетита и магнетита. Фактор Кенигсбергера у всех образцов базальтов лежит в интервале 1.5-16.6, и они, вероятно, являются основным источником наблюдаемых магнитных аномалий, создаваемых подводным вулканическим массивом Рикорда.

Установлены субвертикальное, юго-западное и юго-юговосточное направления подводящих каналов и наличие периферических магматических очагов на глубине 2 км.

Построена объемная модель центральной части вулканического массива Рикорда в которой выделено 10 крупных магнитовозмущающих блоков, которые, вероятнее всего, являются застывшими субвертикальными магмоподводящими каналами.

Работа выполнена при поддержке РФФИ (проекты № 15-05-02955-а и № 15-05-01823-а).

\section{СПИСОК ЛИТЕРАТУРЫ}

Аникин Л.П., Блох Ю.И., Бондаренко В.И. и др. Новые данные о строении подводных вулканов и островов
Курильской островной дуги // Материалы XX региональной научной конференции "Вулканизм и связанные с ним процессы”, посвященной Дню вулканолога, 30-31 марта 2017 г. Петропавловск-Камчатский: ИВиС ДВО РАН, 2017. С. 94-97.

Бабаяни П.С., Блох Ю.И., Бондаренко В.И. и др. Применение пакета программ структурной интерпретации СИГМА-3D при изучении подводных вулканов Курильской островной дуги // Вестник КРАУНЦ. Науки о Земле. 2005. № 2. Вып. 6. С. 67-76.

Бабаяни П.С., Блох Ю.И., Трусов А.А. Интерпретационная томография по данным гравиразведки и магниторазведки в пакете программ “СИГМА-3D" // Вопросы теории и практики геологической интерпретации гравитационных, магнитных и электрических полей. Материалы 31 сессии Международного семинара им. Д.Г. Успенского. М.: ОИФЗ РАН, 2004. С. 88-89.

Безруков Л.П., Зенкевич Н.Л., Канаев В.Ф., Удинцев Г.Б. Подводные горы и вулканы Курильской островной гряды // Труды Лаборатории вулканологии. 1958. Вып. 13. С. 71-88.

Блох Ю.И., Бондаренко В.И., Долгаль А.С. и др. Новые данные о строении подводных вулканических массивов Рикорда и Ратманова (Курильская островная дуга) // Вопросы теории и практики геологической интерпретации геофизических полей. Материалы 44-й сессии Международного семинара им. Д.Г. Успенского, Москва, 23-27 января 2017 г. М.: ИФЗ РАН, 2017. C. 53-58.

Блох Ю.И., Бондаренко В.И., Долгаль А.С. и др. Современные интерпретационные технологии при комплексном моделировании подводного вулкана Макарова (Курильская островная дуга) // Геоинформатика. 2012. № 4. С. 8-17.

Блох Ю.И., Бондаренко В.И., Долгаль А.С. и др. Комплексные геофизические исследования массива Рикорда (Курильская островная дуга) // Материалы региональной конференции "Вулканизм и связанные с ним процессы”, посвященной Дню вулканолога, 2930 марта 2013 г. / Отв. ред. акад. РАН Гордеев Е.И. Петропавловск-Камчатский: ИВиС ДВО РАН, 2013. С. 167-173.

Блох Ю.И., Бондаренко В.И., Долгаль А.С. и др. Подводный вулканизм Охотоморского склона Центральных Курил // Геологические процессы в обстановках субдукции, коллизии и скольжения литосферных плит. Материалы Второй Всероссийской конференции с международным участием, Владивосток, 17-20 сентября 2014 г. Владивосток: Дальнаука, 2014. С. 16-19.

Блох Ю.И., Каплун Д.В., Коняев О.Н. Возможности интерпретации потенциальных полей методами особых точек в интегрированной системе "СИНГУЛЯР" // Известия вузов. Геология и разведка. 1993. № 6. C. $123-127$.

Блох Ю.И., Рашидов В.А., Трусов А.А. Оценка остаточной намагниченности подводных вулканов Курильской островной дуги с применением программы ИГЛА // Вестник КРАУНЦ. Науки о Земле. 2015. № 2. Вып. 26. C. $5-10$.

Блох Ю.И., Трусов А.А. Программа “IGLA” для интерактивной экспресс-интерпретации локальных гравитационных и магнитных аномалий // Вопросы теории и практики геологической интерпретации геофизиче- 
ских полей. Материалы 34-й сессии Международного семинара им. Д.Г. Успенского. М.: ИФЗ РАН, 2007. C. 36-38.

Бондаренко В.И. Строение вулканической впадины бухты Кратерной (Курильские острова) по данным сейсмоакустических исследований // Вулканология и сейсмология. 1986. № 5. С. 96-100.

Бондаренко В.И. Строение и предполагаемая история развития вулканического массива Ушишир (Центральные Курилы) // Геология морей и океанов. Материалы XXI Международной научной конференции (Школы) по морской геологии. Т. V. М.: ГЕОС, 2015. C. $48-52$.

Бондаренко В.И., Рашидов В.А. Геоморфология и тектоника Средних Курил // Геология морей и океанов. Материалы XVII Международной научной конференции (Школы) по морской геологии. T. IV. М.: ГЕОС, 2007. С. 32-33.

Бондаренко В.И., Рашидов В.А. Особенности неотектоники центрального звена Курильской островной дуги // Физика геосфер. Седьмой Всероссийский симпозиум. 5-9 сентября 2011 г. Материалы докладов. Владивосток: Дальнаука, 2011a. С. 390-393.

Бондаренко В.И., Рашидов В.А. Подводные вулканы Центральных Курил // Вулканизм и геодинамика. Материалы V Всероссийского симпозиума по вулканологии и палеовулканологии, 21-25 ноября 2011 года, г. Екатеринбург. Екатеринбург: ИГГ УрО РАН, 20116. C. 404-406.

Горшков Г.С. Вулканизм Курильской островной дуги. М.: Наука, 1967. 287 c.

Дир Х.А., Хауи Р.А., Зусман Джс. Породообразующие минералы. М.: Мир, 1965. Т. 2. 405 с.

Камчатка, Курильские и Командорские острова: история развития рельефа. М.: Наука, 1974. 440 с.

Леликов Е.П., Емельянова Т.А. Вулканогенные комплексы Охотского и Японского морей (сравнительный анализ) // Океанология. 2007. Т. 47. № 2. С. 294-303.
Подводный вулканизм и зональность Курильской островной дуги / Отв. ред. акад. Пущаровский Ю.М. М.: Наука, 1992. 528 с.

Природа магнитных аномалий и строение океанической коры / Отв. ред. Городницкий А.М. М.: ВНИРО, 1996. $283 \mathrm{c}$.

Прокопьев А.В., Фридовский В.Ю., Гайдук В.В. Разломы (Морфология, геометрия и кинематика) / Учеб. пособие / Отв. ред. Парфенов Л.М. Якутск: ЯФ Изд-во СО PAH, 2004. $148 \mathrm{c}$.

Рашидов В.А., Пилипенко О.В., Ладыгин В.М. Сравнительный анализ магнитных свойств пород пяти действующих подводных вулканов западной части Тихого океана // Вулканология и сейсмология. 2014. № 3. C. 37-52.

Рашидов В.А., Пилипенко О.В., Петрова В.В. Петромагнитные и микрозондовые исследования пород подводной вулканической группы Софу (Идзу-Бонинская островная дуга, Тихий океан) // Вулканология и сейсмология. 2015. № 3. С. 36-51.

Рашидов В.А., Пилипенко О.В., Петрова В.В. Петромагнитные и петрографо-минералогические исследования горных пород, драгированных на подводных вулканах Охотоморского склона северной части Курильской островной дуги // Физика Земли. 2016. № 4. С. 84-106.

Тевелев Ал.В., Тевелев Арк.В. Сопряженное развитие вулканогенно-осадочных впадин и магматических камер в условиях присдвигового растяжения // Доклады PAH. 1996. T. 346. № 5. C. 653-655.

Day R., Fuller M., Schmidt V.A. Hysteresis properties of titanomagnetites: grain-size and compositional dependence // Physics of the Earth and Planetary Interiors. 1977. V. 13. P. 260-267.

Ishizuka Y., Nakagawa M., Baba A. et al. Along-arc variations of $\mathrm{K}-\mathrm{Ar}$ ages for the submarine volcanic rocks in the Kurile Islands // Abstracts of the 7th Biennial Workshop on Japan-Kamchatka-Alaska Subduction Processes (JKSP2011). Petropavlovsk-Kamchatskiy, Russia, august 25-30, 2011. P. 279. 